\section{AKTIVITY ÚZIS ČR - KATEGORIZACE ZDRAVOTNICKÉ TECHNIKY}

\section{Kristýna Matušková, Miroslav Zvolský}

\section{Anotace}

Na rozdíl od léků či diagnóz, oblast zdravotnické techniky nevykazuje užívání světově uznávaného jednotného klasifikačního systému. Ve světě je často uplatňována různorodá skupina existujících klasifikačních systémů přímo či neprímo zaměřených na zdravotnickou techniku. Jednotné používání nomenklatury zdravotnických prostředků ve všech členských státech Evropské unie by tak umožňovalo spolupráci mezi př́slušnými kompetentními autoritami státu, poskytovateli zdravotní péče, výrobci, distributory, notifikovanými osobami a ostatními zainteresovanými subjekty. Snahou o sjednocení stávajících př́stupů ke klasifikaci zdravotnických prostředků, zejména pak prostředků charakteru přístrojové techniky, je projekt „Kategorizace zdravotnické techniky“ koordinovaný Ústavem zdravotnických informací a statistiky ČR.

\section{Klíčová slova}

zdravotnická přistrojová technika, klasifikační systém, zdravotnické prostředky

Třídění zdravotnických prostředků je potřebné pro sběr a výměnu dat $v$ prostředí elektronického zdravotnictví, pro tvorbu smluvních a úhradových systémů ve zdravotnictví a pro popis a kontrolu kvality poskytnuté péče. Klasifikační a nomenklaturní systémy slouží k identifikaci zdravotnických prostředků, tedy k vlastnímu popisu výrobků a orientaci např́ic produktovou hierarchií.

Systematizační nástroje se stávají důležitou součástí takřka všech procesních úrovní, at' už při uvádění nových zdravotnických prostředků do tržního prostředí, při managementu nežádoucích príčin, regulaci prostřednictvím legislativních nařízení apod.

Požadavky na jednotlivé klasifikační systémy zdravotnických prostředků jsou charakteristické v závislosti na národních specifikách zdravotnického systému. Je u nich kladen důraz na terminologickou a obsahovou přesnost, úplnost a logické uspořádání hierarchie. Národně nebo nadnárodně používaná klasifikace nese požadavek i stran snadné aktualizace s ohledem na dynamický vývoj trhu v reakci na stávající trendy léčby i nově zaváděné technologie/postupy.

Klíčovou se však stala myšlenka na vývoj a aplikaci jednotného a celosvětově uznávaného systému mezinárodně respektovaných termínů využívaných k identifikaci zdravotnických prostředků platných pro široké spektrum oblastí ve zdravotnictví. Takový systém znamená možnost uživání společného jazyka pro všechny zúčastněné strany jednající o zdravotnických prostředcích, at’ už v roli výrobce, poskytovatele zdravotnických služeb, regulátora a dalších a zároveň umožňuje mezinárodní srovnání a přeshraniční datovou interoperabilitu. K mezinárodním systémům se řadí především GMDN neboli „The global medical device nomenclature". [1] GMDN je systém mezinárodně uznávaných termínů využívaných k identifikaci zdravotnické príistrojové techniky téměř ve všech oblastech zdravotnictví jako je prevence, monitoring, léčba či diagnostika. Tato nomenklatura byla vytvořena dle mezinárodní normy ISO 15225 [2] definující pravidla vytvoření nomenklatury zdravotnických prostředků a byla sestavena a inspirována staršími světovými nomenklaturami jako např́klad ECRI-UMDNS [3] a FDA Product Classification [4]. Uvedené systémy však mají pro oblast zdravotnické techniky různá omezení, často spočívající v nedostatečném detailu nebo aktuálnosti a přesnosti obsahu.

S cílem usnadnit fungování Evropské databáze zdravotnických prostředků (Eudamed) je v současné době evropskou komisí, s odkazem na Nařízení Evropského parlamentu a Rady (EU) - článek 26 nařízení 745/2017 o zdravotnických prostředcích [5], usilováno o zavedení italské nomenklatury CND (Classificazione Nazionale dei Dispositivi Medici), jako oficiální evropské nomenklatury zdravotnických prostředků. [6]

Projekt Kategorizace zdravotnické techniky (KZT) vznikl z potřeby jednotné klasifikace $v$ ČR používaných skupin zdravotnické techniky a identifikace těchto skupin ve sběrech dat Národního zdravotnického informačního systému (NZIS) spravovaného Ústavem zdravotnických informací a statistiky ČR (ÚZIS ČR). Obsahově pak vychází z projektu Podpora systematizace př́strojů (POSYP), který byl realizovaný Národním referenčním centrem v letech 2009-2013, zároveň však reflektuje mezinárodní standardy a systémy terminologie zdravotnických prostředků.

Kategorizace zahrnuje několik možných oddílů s ohledem na oblast využívání př́slušné skupiny přístrojů. Kličcovými oddíly tak jsou:

\section{- Diagnostické prístroje (D) \\ - Terapeutické př́ístroje (T) \\ - Laboratorní prístroje (L)}

Uvedené oddíly obsahují logicky členěné celky dle předem definovaných kritérií, tzv. skupiny. Zařazování zdravotnických přistrojů do př́slušných skupin je prováděno na základě identifikace pomocí kolektivních termínů, synonym či definice. U takových zdravotnických přistrojů, které lze zařadit do většího množství oddílů (např. technika užívaná zároveň pro diagnostiku a terapii pacienta), je na základě odborného posouzení zvolen oddíl primární, kam je př́slušná skupina zařazena a následně je taková opatřena kolektivními termíny.

Každá skupina zdravotnických přístrojů je dále dělena do jedné či více hladin na základě hodnot stanovených technických parametrů, které jsou pro danou skupinu př́strojů charakteristické a významné. Každá hladina reprezentuje splnění požadovaného minima pro zajištění kvality poskytovaných služeb a minimální bezpečnosti pro pacienta, ale i zdravotnický personál.

Kategorizace v současné době obsahuje bezmála 2000 skupin prístrojů $v$ několika hierarchických úrovních. Nejpodrobnější úroveň obsahuje výčet technických parametrů klíčových pro danou skupinu prístrojů. Snahou KZT je, svým rozsahem pojmenovaných skupin, postihnout co možná nejširší výčet přístrojového vybavení používaného ve zdravotnických zařízeních na území celé ČR. [7] [8]

Spektrum možností využití validovaného a nadále vyvíjeného systému je široké. KZT může být využita jako podpůrný zdroj informací ke strategickému plánování prostřednictvím standardizovaného mapování regionálního pokrytí diagnostickými a terapeutickými přístroji z dat národních registrů (př. Národní registr hrazených zdravotních služeb) a k standardizaci a kultivaci sběrů dat (výkaznictví v rámci statistické služby Ministerstva zdravotnictví).

Pokud bude realizována pravidelná revize kategorizace, bude možné $v$ dlouhodobém časovém hledisku analyzovat a predikovat vývoj cen konkrétních skupin prístrojů, přičemž nabízenou možností využití zůstává i kultivace informačního systému Ministerstva zdravotnictví ČR pro potřeby sledování nákupů zdravotnických prístrojů a k poskytování přístupu k aktuálním a věrohodným informacím o nakoupených a provozovaných zdravotnických prístrojích.

Je třeba mít na paměti, že klasifikační systém podobného rozsahu a podrobnosti nelze vyvinout jednorázově. Součástí by měl být právě dlouhodobý rozvoj a kultivace struktury i obsahu, reflexe změn reálné praxe i určujících mezinárodních standardů 
a také navazující podpora - metodiky, popularizace řešení (publikace, odborné akce) školení, integrace do informačních systémů jak obecných (systémy sběru dat na národní úrovni), tak konkrétních (elektronické informační systémy v organizacích). V neposlední řadě je však nutné i legislativní ukotvení KZT a návaznost na klasifikaci dalších skupin zdravotnických prostředků.

\section{Literatura:}

[1.] GMDN Agency [online]. United Kingdom: GMDN Agency, 2020 [cit. 2020-02-17]. Dostupnéz: https://www.gmdnagency.org/

[2.] ISO 15225:2016. Medical devices — Quality management — Medical device nomenclature data structure. 3rd ed. Switzerland: International Organization for Standardization, 2016-03.

[3.] Universal Medical Device Nomenclature System [online]. Spojené státy: ECRI Institute, 2020 [cit. 2020-02-17]. Dostupné z: https://www. ecri.org/solutions/umdns

[4.] Product Classification [online]. Spojené státy americké: U.S. Food and Drug Administration, 2020 [cit. 2020-02-17]. Dostupné z: https:// www.accessdata.fda.gov/scripts/cdrh/cfdocs/cfpcd/classification. cfm

[5.] Regulation (EU) $2017 / 745$ of the European Parliament and of the Council of 5 April 2017 on medical devices, amending Directive 2001/83/EC, Regulation (EC) No 178/2002 and Regulation (EC) No 1223/2009 and repealing Council Directives 90/385/EEC and 93/42/ EEC (Text with EEA relevance.) OJ L 117, 5.5.2017, p. 1-175 (BG, ES, CS, $D A, D E, E T, E L, E N, F R, G A, H R, I T, L V, L T, H U, M T, N L, P L, P T, R O, S K, S L$, Fl, SV); ELI: http://data.europa.eu/eli/reg/2017/745/oj

[6.] Classificazione Nazionale (CND) [online]. Roma: Ministero del Lavoro, della Salute e delle Politiche Sociali Settore Salute, 2020 [cit. 202002-17]. Dostupné z: https://web.archive.org/web/20090805225933/ http://www.ministerosalute.it/dispositivi/paginainterna.jsp?i$d=328 \&$ menu=strumentieservizi

[7.] Metodika kategorizace ZT [online]. 3. doplněné vydání. Praha: Ústav zdravotnických informací a statistiky ČR, 2019 [cit. 2020-02-17]. Dostupnéz: https://www.uzis.cz/index.php?pg=registry-sber-dat--klasifikace--kategorizace-zdravotnicke-techniky\#publikace

[8.] Základní ćíselník kategorií ZT [online]. 3. doplněné vydání. Praha: Ústav zdravotnických informacía statistiky ČR, 2019 [cit. 2020-02-17]. Dostupné z: https://www.uzis.cz/index.php?pg=registry-sber-dat--klasifikace--kategorizace-zdravotnicke-techniky\#publikace

\section{Kontakt:}

Ing. Kristýna Matušková e-mail: kristyna.matuskova@uzis.cz MUDr. Miroslav Zvolský Ústav zdravotnických informací a statistiky ČR Oddělení klinických klasifikací

DRG

Palackého nám. 4

12801 Nové Město 